\title{
KESEJAHTERAAN SUBJEKTIF: HALANGAN DAN CABARAN PESERTA PROGRAM MIKRO KREDIT AMANAH IKHTIAR MALAYSIA DI CAWANGAN KEPONG, WILAYAH SELANGOR DAN KUALA LUMPUR TENGAH
}

\author{
(SUBJECTIVE WELL-BEING: OBSTACLES AND CHALLENGES OFAMANAH IKHTIAR \\ MALAYSIA MICRO CREDIT PROGRAMME PARTICIPANTS FROM THE KEPONG, REGION \\ OF SELANGORAND CENTRAL KUALA LUMPUR BRANCHES)
}

Nik Shahrizan Nik Mad

Akademi Pengajian Melayu, Universiti Malaya

Malaysia

nsnm@um.edu.my

Marzudi Md Yunus

Akademi Pengajian Melayu, Universiti Malaya

Malaysia

marzudi@um.edu.my

Muhammad Shamsinor Abdul Azziz

Pusat Latihan Intern \& Pengayaan Akademik (CITrA), Universiti Malaya

Malaysia

shamshinor@um.edu.my

Received: 11 August 2020; Accepted: 9 November 2020

\begin{abstract}
This study aimed to examine the subjective well-being of Amanah Ikhtiar Malaysia (AIM) participants from the Kepong, Region of Selangor and Central Kuala Lumpur branches. Community development programs such as AIM's typically set performance objectives based on changes in the amount of income received by participants before and after the program. However, this study examined the views and opinions of participants with regards to the overall quality of their lives. Selected participants of the study comprise those who have participated in the AIM program for at least six (6) months. Research methods and assessments were not only limited to physical changes but also the psychology of the participants. As such, subjective assessment was not only done based on the achievements, amount of money (income) and property owned but it went beyond. In this case, the participants were not only evaluated in the aspect of ownership but they were also assessed on their levels of satisfaction towards health, education, societal and personal achievements (dreams). 13 indicators of subjective well-being were used, but only three (3) most dominant ones were assessed based on the views and opinions of the participants in relation to their subjective well-being.
\end{abstract}




\begin{abstract}
Abstrak
Kajian ini adalah bertujuan untuk meneliti tahap kesejahteraan subjektif dalam kalangan peserta program Amanah Ikhtiar Malaysia di Cawangan Kepong, Selangor dan Kuala Lumpur Tengah. Program berteraskan pembangunan komuniti seperti Amanah Ikhtiar Malaysia (AIM) secara kebiasaannya menetapkan objektif pencapaian berasaskan kepada perubahan terhadap jumlah pendapatan yang diterima oleh para peserta sebelum dan selepas menyertai program. Namun begitu, kajian ini meneliti pandangan dan pendapat daripada peserta program berkenaan dengan kualiti kehidupan mereka secara keseluruhan. Peserta program yang dipilih terdiri daripada mereka yang telah menyertai program AIM sekurang-kurangnya selama enam (6) bulan. Kaedah penelitian dan penilaian bagi kajian ini tidak terhad terhadap perubahan fizikal sahaja, namun juga melibatkan psikologi peserta. Hal ini bermakna penilaian subjektif tidak hanya berdasarkan pencapaian, pemilikan wang (pendapatan) dan harta benda sahaja, sebaliknya melebihi daripada aspek tersebut. Justeru, peserta bukan sahaja dinilai berdasarkan aspek pemilikan sahaja, tetapi turut dinilai berdasarkan tahap kepuasan hidup dari segi kesihatan, pendidikan, sosial dan pencapaian dalam diri (impian). Sebanyak 13 indikator kesejahteraan subjektif digunakan bagi tujuan penilaian tahap kesejahteraan, namun hanya tiga (3) indikator yang paling dominan dinilai berdasarkan kepada pandangan dan pendapat peserta berkaitan kesejahteraan subjektif mereka.
\end{abstract}

Kata kunci: Kesejahteraan subjektif, kepuasan, kegembiraan, mikro kredit, Amanah Ikhtiar Malaysia.

\title{
Pendahuluan
}

Sejak mencapai kemerdekaan pada tahun 1957, antara masalah dan topik yang sering dibincangkan berkenaan dengan orang Melayu adalah berkaitan dengan ekonomi atau lebih tepat lagi adalah mengenai kemiskinan dan cabaran yang dihadapi orang Melayu. Dalam tempoh 61 tahun (19572018) pelbagai usaha dan program telah dijalankan oleh kerajaan untuk membasmi kemiskinan dalam kalangan orang Melayu. Kerajaan memfokuskan usaha membasmi kemiskinan dalam kalangan orang Melayu yang merupakan penduduk asal negara ini kerana dari segi kemampuan ekonomi dan pemilikan harta adalah tidak memihak kepada orang Melayu berbanding dengan dua kaum lain, iaitu Cina dan India. Hal ini adalah berdasarkan kepada laporan Unit Perancangan Ekonomi, Jabatan Perdana Menteri (2017).

Kualiti hidup diukur melalui pelbagai indeks dan bidang yang berbeza. Kualiti hidup juga menggambarkan indikator kemajuan dan pencapaian sesebuah negara. Perkara yang diberi perhatian dalam Indeks Pembanguan Manusia(IPM) adalah berkaitan dengan kesihatan, pendidikan dan pendapatan (Grimm et. al, 2008). Indikator ini adalah saling berkait rapat dan perlu seimbang dalam melihat pembangunan manusia. Berdasarkan kepada Dewi (2017), salah satu indeks yang dilihat dalam IPM adalah kuasa beli (pemilikan) oleh masyarakat. Dalam usaha membasmi kemiskinan dan penyusunan semula masyarakat, kerajaan persekutuan telah memperkenalkan Dasar Ekonomi Baru pada tahun 1970 berikutan kadar kemiskinan orang Melayu pada waktu itu mencapai 64.8\% (Pejabat Perdana Menteri, 2017). Kerajaan telah melakukan pelbagai usaha untuk meningkatkan kesejahteraan hidup rakyat. 
Menurut Abd. Wahab et al. (2013), kerajaan telah melakukan pelbagai usaha untuk meningkatkan kesejahteraan hidup rakyat. Antara usaha membasmi kemiskinan melalui projek pembangunan komuniti seperti projek Kemajuan Masyarakat (KEMAS), Federal Land Development Authority (FELDA), Gerakan Desa Wawasan (GDW), Projek Kesejahteraan Rakyat (PPRT) dan projek Amanah Ikhtiar Malaysia (AIM) berdasarkan kepada Chamhuri \& Surtahman (2000). Program AIM adalah sebahagian dari pendekatan pembangunan komuniti yang menjalani proses transformasi hasil dari pembangunan luar bandar (Abd. Wahab, 2010). Pembangunan luar bandar membawa kesan yang menyeluruh kepada orang Melayu (Wan Yusoff, 2007).

Indeks kesejahteraan manusia diukur secara objektif dan juga subjektif. Ukuran objektif lebih menumpukan kepada aspek ekonomi dan pemilikan individu. Ukuran subjektif pula lebih menumpukan penilaian tahap kegembiraan seseorang berhubung dengan kualiti kehidupan mereka secara keseluruhan (Diener \& Diener, 2001). Perubahan corak hidup dan sosio-ekonomi akan memberi kesan kepada tahap kesejahteraan manusia. Kesan tersebut boleh ditakrifkan sebagai kecil dan besar, serta berbeza antara individu dalam sesuatu kelompok masyarakat.

\section{Permasalahan Kajian}

Sejak AIM ditubuhkan pada tahun 1987, pelbagai kajian telah dilakukan mengenai perubahan yang dialami oleh para peserta program. Akan tetapi, kebanyakan kajian adalah berkaitan dengan perubahan penjanaan pendapatan peserta sebelum dan selepas menyertai program. Namun begitu, kajian ini lebih menumpukan kepada permasalahan berkaitan dengan cabaran dan halangan peserta program berkaitan dengan projek yang dilaksanakan. Seterusnya, adakah halangan dan cabaran ini memberi kesan terhadap kesejahteraan subjektif dalam kalangan peserta AIM?

\section{Metodologi Kajian}

Berdasarkan kajian ini, pendekatan yang digunakan adalah kualitatif dan kuantitatif. Kaedah campuran (mixed method research) diterapkan untuk mendapatkan keseimbangan data dan membantu menguatkan dapatan kajian. Soal selidik diedarkan kepada 400 orang responden program AIM, berdasarkan populasi pada kadar 1345 orang, dengan confidence level 95\%, margin of error 5\%, jumlah responden yang dicadangkan adalah 300 orang. Seramai 309 orang responden telah menjawab soal selidik yang diedarkan. Data soal selidik diproses menggunakan perisian Statistical Package for Social Sciences (SPSS). Kaedah temu bual dijalankan secara individu dan berkumpulan secara berstruktur dan tidak berstruktur. Responden yang terlibat dalam temu bual adalah responden yang sama dengan responden yang menjawab soal selidik.

\section{Model 3p \& 3e}

Teori yang digunakan adalah berdasarkan kajian oleh Durayappah (2010) yang menjawab persoalan konsep situasi dan masa seperti 1) How happy I was? 2) How happy I am? 3) How happy I am going to be? 4) who I was? 5) who I am? 6) who I will be? Persoalan ini menjelaskan kehidupan ideal, sasaran dan pencapaian pada masa lalu, masa kini dan masa hadapan. Hal ini membantu memberi jawapan dalam penilaian tahap kesejahteraan subjektif atau subjective wellbeing (SWB) seseorang. Rajah 1 menerangkan keadaan (state) dalam evaluasi SWB bagi setiap responden dan melihat bagaimana keadaan itu bergantung dan juga berantaian antara satu sama lain. 


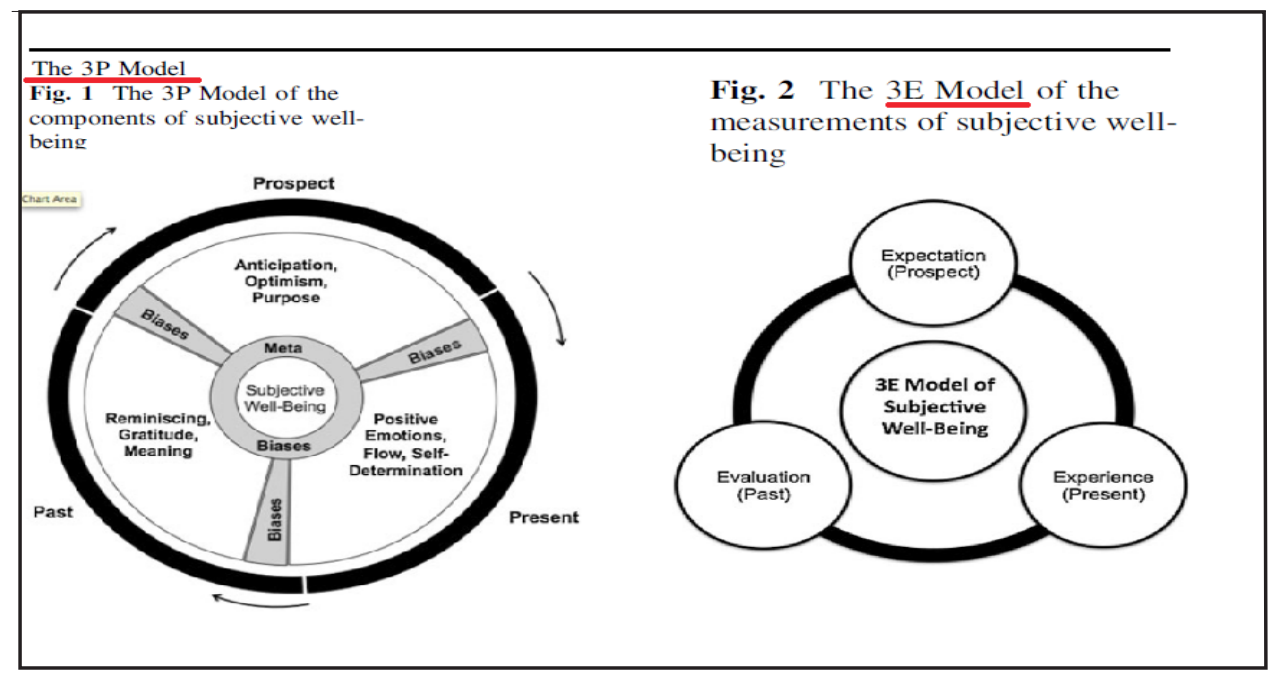

Rajah 1: Model 3P \& 3E bagi Kaedah Ukuran SWB (Durayappah, 2010).

Kesejahteraan subjektif dalam kalangan peserta program juga berkait rapat dengan pencapaian dan kejayaan projek yang diusahakan oleh mereka. Sehubungan dengan itu, bagi melihat tahap kesejahteraan peserta, halangan dan cabaran yang dihadapi akan dikaitkan dengan tahap kesejahteraan subjektif peserta program.

\section{Kajian Literatur}

Bidang kajian berkaitan dengan SWB telah dipelopori oleh Maslow (1943) yang memperkenalkan konsep 5 hierarki senarai keperluan asas. Bermula dengan keperluan physiological needs, safety, lovelaffection, self-esteem dan self-actualization. Setiap satu bahagian perlu dipenuhi secara berperingkat dan satu per satu. Memenuhi atau gagal memenuhi setiap satu keperluan tersebut akan memberi kesan terhadap kepuasan dan kegembiraan kehidupan manusia. Kualiti hidup dinilai dan dikaji dari pelbagai disiplin yang berbeza. Selain itu, kualiti hidup turut dinilai secara objektif dan subjektif. Perbezaan ini dapat dilihat dari perspektif ekonomi, psikologi, kesihatan, sains persekitaran dan sosiologi (Musa et. al, 2016).

Smith \& Clay (2010) menyatakan bahawa SWB adalah antara perkara yang biasa dibincangkan dalam bidang antropologi, ekonomi, psikologi, sosiologi dan bidang lain dalam sains sosial. SWB turut dikenali sebagai kajian tahap kegembiraan dan kepuasan hidup yang merujuk kepada keadaan, emosi dan perasaan (Changingminds.org, 2017). Galloway et. al (2005) menyatakan bahawa SWB ialah pengukuran kualiti hidup yang subjektif dan dilihat dari pelbagai sudut pandangan. Erik Agner (2009) menyatakan SWB adalah sesuatu yang diingini oleh mental dan emosi.

Kegembiraan adalah definisi subjektif berdasarkan kepada SWB, dan berbeza antara setiap individu (Lyubomirsky \& Lepper, 1999). Menurut Kesebir \& Diener (2008), SWB selalu diganti atau pelengkap kepada kajian kesejahteraan tradisi yang berasaskan kepada ukuran ekonomi. Kajian SWB dalam aspek psikologi telah diketengahkan oleh sarjana seperti Caterina \& Salvatore (2016) berkenaan dengan kesejahteraan hidup, kualiti hidup dan kepuasan hidup. Pelbagai konsep sejak perkembangan bidang SWB digunakan seperti "flourishing, thriving, \& prospering" bagi menggambarkan fokus penyelidikan yang dilakukan. Caterina \& Salvatore (2016) membangkitkan 
tema penyelidikan berkait psikologi dalam kehidupan sosial, hubungan dalam keluarga antara dua generasi berbeza, peranan ibu bapa, sokongan sosial, isu imigran, perubahan sosial, komuniti, inisiatif sosial, keadilan sosial, ketaksamaan sosial, perbezaan budaya akan memberi kesan yang berbeza terhadap individu dan komuniti.

Psikologi dalam SWB juga sering dikaji menggunakan pelbagai teori psikologi. Antara teori yang digunakan adalah homeostatic model, multiple discrepancies theory dan structural equation model. Model Homeostatic dikritik dalam kajian Belinda Davey (2004), beliau menyatakan ketidaksesuaian memahami SWB berdasarkan model tersebut yang cenderung menggunakan pendekatan kemurungan dan depresi dalam menilai kesejahteraan hidup. SWB bukan berkenaan dengan kemurungan dan depresi sahaja, namun merangkumi pelbagai aspek kehidupan psikologi seseorang. Pendekatan psikologi adalah sebahagian daripada bidang sosiologi dalam kajian SWB. Kajian oleh Veenhoven (2008) berkenaan cabang sosiologi mendapati antara teori yang digunakan adalah social comparison theory, psychological theory (affective \& cognitive), livability theory, modernity theory (Gemeinschaft \& Gesselschaft) serta welfare state theory yang menerangkan bahawa SWB merupakan satu komponen dalam social behavior. Veenhoven (2008) menyenaraikan hubungan bersama keluarga, rakan-rakan, masyarakat dan pengalaman lalu yang memberi kesan terhadap domain afektif. Perbezaan budaya, kepentingan peribadi, keperluan psikologi, tahap pembangunan yang dicapai, kelas masyarakat, welfare state, ketaksamaan sosial, penglibatan dalam masyarakat, dan sokongan sosial yang memberi makna kepada kesejahteraan seseorang.

Penyelidikan oleh Kroll (2011) berkaitan dengan SWB dalam Teori Modal Sosial berhubung aspek gender, umur, status ibu bapa, status perkahwinan mendapati indikator yang mempunyai kolerasi adalah status pekerjaan, agama, pemilikan anak, tahap pendidikan, status warganegara dan personaliti individu memainkan peranan penting dalam menentukan tahap kesejahteraan hidup seseorang. Namun, dapatan kajian menunjukkan silang aspek, iaitu mendapati perbezaan antara dua kumpulan umur, gender, pendapatan, status perkahwinan, pemilikan anak adalah berbeza terhadap nilai dan kepercayaan, hubungan sivik, dan proses sosialisasi.

Keyes (1998) membincangkan perihal social integration, social contribution, social coherence, social actualization dan social acceptance. Keyes mengkaji Teori Peranan dan Teori Struktur Sosial, yang mendapati SWB adalah lebih luas berbanding pemilihan beberapa indikator sahaja. Antara aspek yang dikaji oleh Keyes adalah umur (muda, pertengahan, tua), gender, status perkahwinan (berkahwin, bujang dan lain-lain), bangsa, tahap pendidikan, pendapatan yang menggunakan kaedah soal selidik dan dianalisis menggunakan kaedah statistik.

Kerce, E.W. (1992) menjalankan penyelidikan berhubung ukuran kesejahteraan dan kualiti kehidupan. Beliau mencadangkan beberapa kaedah pengukuran seperti Subjective Quality of Live (SQL), Delight to Terrible Scale, Life Domains dalam kertas yang disediakan, dan cadangan aplikasi teori dan model seperti structural equation model (affect, cognition, random error \& measurement error) dan model Basic Domain/life as a whole (LAW). Wan Ibrahim et. al (2009) dalam kajian berkenaan SWB ke atas warga tua seramai 214 orang di Kelantan mendapati keputusan kajian yang menggunakan kaedah analisis regrasi mendapati tahap pendidikan, pengalaman kerja, pemilikan rumah, hubungan sosial dengan keluarga, rakan dan jiran mempunyai pengaruh yang tinggi terhadap kesejahteraan hidup warga tua di Kelantan. Kajian ini menilai sejauh mana warga tua mencapai kepuasan berkenaan pendapatan, pola perbelanjaan, pemilikan barangan isi rumah dan harta, berpuas hati dengan tahap kesihatan.

e ISSN 2735 - 1904

https://doi.org/10.22452/JOMAS.vol31no1.2 
Menurut Paul Dolan et.al (2008), kebanyakan kajian melakukan perbandingan model dan kaedah yang berbeza. Faktor kawalan yang ditetapkan oleh pengkaji menyebabkan data berbeza sekiranya dibandingkan antara satu sama lain. Antaranya topik yang menjadi pilihan dalam SWB adalah pendapatan, karektor peribadi, karektor pembangunan oleh sosial, bagaimana masa luang digunakan, sikap/kepercayaan terhadap diri, orang lain dan juga hidup, hubungan dan aspek ekonomi yang luas, sosial dan persekitaran politik. Perbezaan tahap kepuasan dan kesejahteraan hidup antara dua puak yang sama, namun berbeza dari sudut lokasi tempat tinggal juga merekodkan perbezaan tahap kepuasan yang berbeza. Dapatan kajian oleh Robert \& Andrew (2017) menunjukkan budaya baru yang disemai dalam pemikiran dan kehidupan masyarakat akan memberikan satu pandangan atau tahap minima pencapaian yang berbeza antara satu sama lain. Hal ini jelas menunjukkan bahawa terdapat banyak potensi lain yang mempengaruhi keputusan kajian dalam aspek yang sama namun berbeza lokasi dan pengaruh persekitaran yang berbeza.

Bagi aspek sosial dalam SWB antara perkara yang memberi kesan adalah sistem kekeluargaan, struktur sosial dan kehidupan secara keseluruhan selain dari aspek fizikal dan kebendaan (Heather Randall, 2016). Diener (2006) pula menyatakan bahawa salah satu kaedah penyelidikan bagi mengkaji SWB adalah berkaitan isu bukan kewangan. Salah satu contoh adalah migrasi yang diakibatkan oleh perubahan ekonomi, politik, pembangunan dan sebagainya boleh membawa kepada perubahan yang besar dalam kehidupan. Perubahan kehidupan ini juga melibatkan perubahan persepsi terhadap kehidupan dan juga kesejahteraan hidup. Sementara itu, kajian Arnold Matzdorff (2015) yang menggunakan Teori 3E \& 3P (Durayappah, A. 2010) dalam menilai tahap kesejahteraan kanak-kanak sekolah di Cape Town yang menggunakan dua bahasa berbeza (Inggeris dan Afrika). Kajian mendapati bahawa kanak-kanak yang menggunakan bahasa Afrika kurang tahap kesejahteraan subjektif berbanding kanak-kanak yang menggunakan bahasa Inggeris kerana dasar kerajaan terdahulu (apartheid) yang membezakan pembangunan, interaksi kaum (berdasarkan warna kulit). Walaupun perbezaan antara kumpulan tidak signifikan, namun terdapat perbezaan dilihat dari segi regresi, kolerasi dan nilai min antara kumpulan tersebut.

\section{Analisis Halangan dan Cabaran}

Terdapat sepuluh (10) jenis halangan dan cabaran yang dikenal pasti dalam kajian ini. Namun begitu, kajian ini hanya memfokuskan kepada dua bentuk halangan dan cabaran yang menjadi pilihan majoriti responden, iaitu sikap serta pasaran dan persaingan. Faktor ini paling relevan dan memberi kesan kepada responden berbanding faktor lain.

\section{Sikap}

Antara faktor utama penyumbang kepada perkembangan, kejayaan dan pertumbuhan projek usahawan adalah sikap responden itu sendiri. Sikap ini melibatkan psikologi, keupayaan untuk berubah, pengalaman, potensi, produktiviti, penetapan matlamat, persediaan dan kebolehan diri. Kemampuan responden mengenal pasti kelemahan, kekuatan, persaingan dan peluang juga adalah antara kunci kepada kejayaan projek yang mereka usahakan. 


\subsection{Kumpulan Umur Berbanding Faktor Sikap}

Terdapat lima (5) kumpulan umur responden seperti berikut dalam Jadual 1.

Jadual 1: Kumpulan umur (kajian lapangan, 2019).

\begin{tabular}{|llcccc|}
\hline & \multicolumn{1}{c}{ Indikator } & $\begin{array}{c}\text { Tidak } \\
\text { setuju }\end{array}$ & $\begin{array}{c}\text { tidak pasti } \\
/ \text { tiada } \\
\text { perubahan }\end{array}$ & setuju & Jumlah \\
& $21-30$ tahun & 0 & 0 & 21 & 21 \\
\multirow{3}{*}{ Umur } & $31-40$ tahun & 0 & 0 & 103 & 103 \\
& $41-50$ tahun & 0 & 0 & 119 & 119 \\
& $51-60$ tahun & 0 & 1 & 60 & 61 \\
Jumlah & 61 tahun ke atas & 0 & 0 & 5 & 5 \\
& & 0 & 1 & 308 & 309 \\
\hline
\end{tabular}

Analisis mendapati kumpulan umur 21- 30 tahun yang bersetuju dengan faktor sikap sebagai halangan dan cabaran adalah seramai 21 orang (100\%). Sementara kumpulan umur 3140 tahun yang bersetuju adalah seramai 103 orang (100\%). Kumpulan umur 41-50 tahun pula seramai 119 orang (100\%), kumpulan umur 51-60 tahun seramai 60 orang (98.5\%), dan seorang responden tidak pasti dengan faktor yang diberikan (1.5\%). Kumpulan umur, 61 tahun ke atas juga mencatat $100 \%$ responden yang bersetuju dengan faktor ini (5 orang). Secara keseluruhannya, didapati bahawa 308 orang responden bersetuju (99.5\%), dengan hanya seorang responden tidak pasti dengan faktor tersebut sebagai halangan dan cabaran terhadap perniagaan dan perusahaan mereka.

\subsection{Tahap Pendidikan Berbanding Faktor Sikap}

Kumpulan tahap pendidikan dikelaskan dalam kalangan responden kajian ini bagi melihat pola jawapan berdasarkan tahap pendidikan. Terdapat enam (6) kumpulan tahap pendidikan seperti dalam Jadual 2.

Jadual 2: Tahap pendidikan (kajian lapangan, 2019).

\begin{tabular}{|c|c|c|c|c|c|}
\hline \multirow{8}{*}{$\begin{array}{c}\text { Tahap } \\
\text { pendidikan } \\
(\mathrm{a} 6)\end{array}$} & Indikator & $\begin{array}{l}\text { Tidak } \\
\text { setuju }\end{array}$ & $\begin{array}{l}\text { tidak pasti } \\
\text { / tiada } \\
\text { perubahan }\end{array}$ & setuju & Jumlah \\
\hline & Tamat sekolah rendah / tidak Bersekolah & 0 & 0 & 12 & 12 \\
\hline & Tamat tingkatan tiga / srp / pmr & 0 & 0 & 66 & 66 \\
\hline & Tamat tingkatan lima /spm & 0 & 1 & 166 & 167 \\
\hline & Sijil & 0 & 0 & 32 & 32 \\
\hline & Diploma / stpm & 0 & 0 & 28 & 28 \\
\hline & Ijazah tinggi (ijazah/sarjana/PhD) & 0 & 0 & 4 & 4 \\
\hline & Jumlah & 0 & 1 & 308 & 309 \\
\hline
\end{tabular}


Analisis menunjukkan bahawa seramai 12 orang (100\%) responden dalam kategori tamat sekolah rendah/tidak bersekolah bersetuju faktor sikap adalah aspek yang penting dalam menentukan kejayaan perniagaan dan perusahaan yang mereka lakukan. Sementara, kumpulan berpendidikan sehingga tamat tingkatan tiga/SRP/PMR menunjukkan seramai 66 orang (100\%) bersetuju dengan aspek sikap adalah halangan dan cabaran kepada kejayaan mereka.

Kumpulan berpendidikan sehingga tamat tingkatan lima/SPM menunjukkan seramai 166 orang $(99.5 \%)$ bersetuju sementara, seorang responden $(0.5 \%)$ direkodkan tidak pasti dengan faktor tersebut. Semua responden yang menamatkan pengajian sehingga peringkat sijil direkodkan bersetuju dengan aspek sikap, iaitu seramai 32 orang (100\%), begitu juga dengan peringkat pengajian sehingga Diploma/STPM (28 orang, 100\%) dan peringkat Ijazah Tinggi (Ijazah/Sarjana/ $\mathrm{PhD}$ ) seramai empat (4) orang (100\%) bersetuju dengan aspek sikap sebagai antara halangan dan cabaran utama dalam mencapai tahap kesejahteraan subjektif mereka.

Secara keseluruhannya, analisis taburan silang antara kumpulan tahap pendidikan dengan jumlah responden menunjukkan seramai 308 orang atau 99.7\% responden daripada pelbagai latar belakang pendidikan bersetuju faktor sikap adalah antara aspek yang penting dalam menentukan kejayaan dan kegagalan perniagaan atau perusahaan yang mereka jalankan. Hanya seorang (1) responden $(0.3 \%)$ direkodkan tidak pasti dengan faktor ini sebagai aspek yang memberi kesan terhadap diri mereka (merujuk kepada impak perniagaan dan perusahaan). Kejayaan dan kegagalan ini akan memberi kesan terhadap tahap kesejahteraan subjektif responden secara tidak langsung. Oleh yang demikian, responden berpandangan bahawa faktor ini adalah antara elemen yang penting dalam kehidupan mereka secara tidak langsung.

\subsection{Jumlah Tanggungan Berbanding Faktor Sikap}

Peserta program dibahagikan kepada lima (5) kumpulan berdasarkan kepada jumlah tanggungan mereka seperti dalam Jadual 3.

Jadual 3: Jumlah tanggungan (kajian lapangan, 2019).

\begin{tabular}{|llcccc|}
\hline & Indikator & $\begin{array}{c}\text { Tidak } \\
\text { setuju }\end{array}$ & $\begin{array}{c}\text { tidak pasti } \\
\text { / tiada } \\
\text { perubahan }\end{array}$ & setuju & Jumlah \\
& Tiada tanggungan & 0 & 0 & 6 & 6 \\
Jumlah & 1-2 orang & 0 & 0 & 53 & 53 \\
tanggungan & 3-4 orang & 0 & 0 & 107 & 107 \\
(a7) & 5-6 orang & 0 & 1 & 119 & 120 \\
& Lebih daripada 7 orang & 0 & 0 & 23 & 23 \\
Jumlah & & 0 & 1 & 308 & 309 \\
\hline
\end{tabular}

Berdasarkan kepada analisis soal selidik yang dijalankan, mendapati seramai enam (6) orang $(100 \%)$ daripada kumpulan responden yang tiada tanggungan bersetuju faktor sikap adalah 
halangan dan cabaran yang utama kepada perkembangan perniagaan dan perusahaan peserta AIM. Keseluruhan (100\%) responden bagi kumpulan mempunyai tanggungan seramai 1-2 orang (53 orang) dan kumpulan responden yang mempunyai tanggungan seramai 3-4 seramai (107 orang) bersetuju dengan faktor tersebut. Sementara itu, kumpulan responden yang mempunyai tanggungan seramai 5-6 orang yang berjumlah 120 orang, seramai 119 orang bersetuju (99.2\%) dan seorang responden $(0.8 \%)$ tidak pasti sama ada faktor berkenaan adalah halangan dan cabaran kepada peserta program. Bagi kumpulan responden yang mempunyai tanggungan melebihi daripada 7 orang adalah seramai 23 orang, keseluruhan responden $(100 \%)$ turut bersetuju dengan faktor berkenaan. Secara keseluruhannya, didapati bahawa daripada 309 orang responden yang terlibat dalam kajian ini, seramai 308 orang atau 99.7\% daripada jumlah populasi kajian bersetuju faktor sikap menjadi halangan dan cabaran kepada peserta program untuk mencapai kejayaan dalam perniagaan dan perusahaan mereka. Hanya seorang (1) responden $(0.3 \%)$ sahaja yang tidak pasti dengan faktor tersebut.

\subsection{Pendapatan Isi Rumah Berbanding Faktor Sikap Peserta Program}

Sebanyak enam (6) kumpulan pendapatan isi rumah dikenal pasti berdasarkan kumpulan responden seperti Jadual 4 di bawah.

Jadual 4: Pendapatan isi rumah (kajian lapangan, 2019).

\begin{tabular}{|llcccc|}
\hline & Indikator & $\begin{array}{c}\text { Tidak } \\
\text { setuju }\end{array}$ & $\begin{array}{c}\text { tidak pasti } \\
\text { / tiada } \\
\text { perubahan }\end{array}$ & setuju & Jumlah \\
Jumlah & Kurang dari RM1000.00 & 0 & 0 & 8 & 8 \\
pendapatan & RM1001.00-RM1999.00 & 1 & 2 & 59 & 62 \\
isi rumah & RM2000.00-RM2999.00 & 0 & 1 & 141 & 142 \\
sebulan *a10 & RM3000.00-RM3999.00 & 1 & 0 & 86 & 87 \\
* & RM4000.00-RM4999.00 & 0 & 0 & 7 & 7 \\
Jumlah & Lebih dari RM5000.00 & 0 & 0 & 3 & 3 \\
\hline
\end{tabular}

Sumber : Kajian lapangan (2019)

Berdasarkan soal selidik yang diedarkan, menunjukkan kumpulan pendapatan isi rumah yang berpendapatan kurang daripada RM1000.00 seramai lapan (8) orang responden, keseluruhan responden (100\%) bersetuju faktor sikap adalah halangan dan cabaran utama dalam perniagaan dan perusahaan yang diusahakan oleh peserta AIM. Peserta berpendapatan isi rumah antara RM10011999.00 adalah seramai 62 orang, seramai 61 orang $(98.4 \%)$ bersetuju dengan faktor sikap sebagai penghalang dan cabaran kepada mereka, dua orang (3.2\%) tidak pasti dan seorang (1.6\%) tidak bersetuju dengan faktor tersebut. Kumpulan isi rumah berpendapatan RM2000-2999.00 pula seramai 142 orang dan keseluruhan responden (100\%) turut bersetuju dengan faktor berkenaan.

Kumpulan responden yang berpendapatan isi rumah antara RM3000-3999.00 seramai 87 orang, seorang responden (1.1\%) tidak bersetuju. Kumpulan berpendapatan RM4000-4999.00 
adalah seramai tujuh (7) orang dan berpendapatan lebih daripada RM5000.00 seramai tiga (3) orang pula menunjukkan bahawa keseluruhan responden (100\%) bersetuju dengan faktor tersebut. Secara keseluruhannya, seramai 304 orang (98.4\%) bersetuju dengan faktor sikap sebagai halangan dan cabaran utama kepada peserta program AIM dalam memastikan perniagaan dan perusahaan mereka berjaya. Tiga orang responden (1\%) tidak pasti dan dua (2) orang responden (0.6\%) tidak bersetuju dengan faktor tersebut.

\section{Pasaran dan Persaingan}

Faktor kedua yang dikenal pasti sebagai penyumbang kepada perkembangan, kejayaan dan pertumbuhan projek peserta program adalah berkaitan dengan pasaran dan persaingan perniagaan dan perusahaan. Persaingan dalam pasaran yang kecil antara peserta program AIM menyebabkan responden menghadapi pelbagai cabaran dan halangan yang timbul akibat daripada perkara ini. Dalam hal ini, saiz pasaran dan bilangan pesaing memainkan peranan penting dalam kesinambungan perniagaan. Ini kerana dalam saiz pasaran yang kecil dan terhad, pemain industri yang ramai menyebabkan pertumbuhan dan perkembangan perniagaan dan perusahaan akan terkesan dengan faktor tersebut. Penilaian terhadap bilangan dan sasaran pengguna juga perlu dilakukan bagi melihat tahap persaingan, potensi pengguna dan pembeli di kawasan berkaitan.

\subsection{Kumpulan Umur Berbanding Faktor Pasaran dan Persaingan}

Dalam bahagian kumpulan umur, terdapat lima (5) kumpulan umur peserta program AIM seperti berikut dalam Jadual 5.

Jadual 5: Umur responden (kajian lapangan, 2019).

\begin{tabular}{|llcccc|}
\hline & Indikator & $\begin{array}{c}\text { Tidak } \\
\text { setuju }\end{array}$ & $\begin{array}{c}\text { tidak pasti } \\
/ \text { tiada } \\
\text { perubahan }\end{array}$ & setuju & Jumlah \\
& $21-30$ tahun & 0 & 0 & 21 & 21 \\
\multirow{3}{*}{ Umur } & $31-40$ tahun & 0 & 1 & 102 & 103 \\
& $41-50$ tahun & 1 & 1 & 117 & 119 \\
& $51-60$ tahun & 1 & 1 & 59 & 61 \\
Jumlah & 61 tahun ke atas & 0 & 0 & 5 & 5 \\
& & 2 & 3 & 304 & 309 \\
\hline
\end{tabular}

Analisis faktor sikap responden berbanding kumpulan umur mendapati kumpulan umur 21- 30 tahun yang bersetuju dengan faktor sikap adalah halangan dan cabaran utama kepada perkembangan perniagaan dan perusahaan mereka adalah seramai 21 orang (100\%). Sementara 
kumpulan umur 31-40 tahun yang bersetuju adalah seramai 103 orang. Seramai 102 orang (99\%) bersetuju dengan faktor tersebut, sementara seorang (1) responden $(0.8 \%)$ tidak pasti dan tiada responden ( $0 \%$ ) tidak setuju dengan faktor tersebut. Bagi kumpulan umur 41-50 tahun, terdapat seramai 119 orang responden, seramai 117 orang (98.4\%) bersetuju, seorang (1) responden $(0.8 \%)$ tidak bersetuju dan seorang(1) responden (0.8\%) tidak pasti dengan faktor tersebut. Kumpulan umur 51-60 tahun, terdapat seramai 61 orang responden yang meliputi 59 orang responden (96.7\%) bersetuju dengan faktor tersebut, seorang (1) responden (1.65\%) tidak pasti dan seorang (1) responden (1.65\%) tidak setuju dengan faktor berkenaan. Sementara itu, kumpulan umur 61 tahun ke atas pula mencatatkan 100\% responden yang bersetuju dengan faktor ini (5 orang). Secara keseluruhannya, didapati bahawa 304 orang responden bersetuju (98.4\%), dengan tiga (3) orang responden ( $1 \%$ ) tidak pasti dengan faktor, dan seorang (1) responden $(0.6 \%)$ tidak bersetuju dengan faktor pasaran dan persaingan sebagai halangan dan cabaran kepada peserta program AIM. Ini menunjukkan bahawa faktor pasaran dan persaingan adalah faktor yang utama sebagai halangan dan cabaran kepada majoriti peserta program.

\subsection{Tahap Pendidikan Berbanding Faktor Pasaran dan Persaingan}

Analisis seterusnya berkenaan dengan hubungan antara tahap pendidikan dengan faktor pasaran dan persaingan yang menjadi halangan dan cabaran kepada peserta program mikro kredit AIM. Terdapat enam (6) kumpulan tahap pendidikan seperti dalam Jadual 6.

Jadual 6: Tahap pendidikan responden (kajian lapangan, 2019).

\begin{tabular}{|llcccc|}
\hline \multicolumn{1}{c}{ Indikator } & $\begin{array}{c}\text { Tidak } \\
\text { setuju }\end{array}$ & $\begin{array}{c}\text { tidak pasti } \\
\text { / tiada } \\
\text { perubahan }\end{array}$ & setuju & Jumlah \\
& Tamat sekolah rendah/tidak bersekolah & 0 & 0 & 12 & 12 \\
Tahap & Tamat tingkatan tiga/srp/pmr & 0 & 0 & 66 & 66 \\
pendidikan & Tamat tingkatan lima/spm & 0 & 2 & 165 & 167 \\
(a6) & Sijil & 1 & 0 & 31 & 32 \\
& Diploma/stpm & 1 & 1 & 26 & 28 \\
Jumlah & Ijazah tinggi (ijazah/sarjana/PhD) & 0 & 0 & 4 & 4 \\
& & 2 & 3 & 304 & 309 \\
\hline
\end{tabular}

Analisis kajian menunjukkan seramai 12 orang (100\%) responden dalam kategori tamat sekolah rendah/tidak bersekolah dan kumpulan berpendidikan sehingga tamat tingkatan tiga/SRP/ PMR seramai 66 orang (100\%) bersetuju dengan faktor pasaran dan persaingan adalah halangan dan cabaran kepada kejayaan mereka.

Bagi kumpulan berpendidikan sehingga tamat tingkatan 5/SPM pula terdapat 167 orang responden. Seramai 165 orang $(98.8 \%)$ bersetuju sementara dua (2) orang responden $(1.2 \%)$ direkodkan tidak pasti dan tiada responden yang tidak bersetuju dengan faktor berkenaan. Kumpulan responden yang menamatkan pengajian sehingga peringkat sijil pula adalah seramai 32 orang yang meliputi 31 orang responden $(96.9 \%)$ bersetuju bahawa faktor pasaran dan persaingan 
merupakan halangan dan cabaran kepada mereka. Seorang (1) responden (3.1\%) didapati tidak bersetuju dengan faktor tersebut. Sementara itu, bagi kumpulan responden yang berpendidikan sehingga Diploma/STPM adalah seramai 28 orang. Berdasarkan jumlah tersebut, seramai 26 orang responden (92.8\%) bersetuju dengan faktor ini, seorang (1) responden (3.6\%) bagi setiap kategori, iaitu tidak pasti dan tidak bersetuju dengan faktor tersebut.

Bagi responden yang menamatkan pengajian sehingga peringkat Ijazah Tinggi (Ijazah, Sarjana/PhD) seramai empat (4) orang, dan keseluruhan (100\%) responden bersetuju dengan faktor pasaran dan persaingan sebagai halangan dan cabaran utama dalam perniagaan dan perusahaan mereka. Kejayaan dan kegagalan dalam perniagaan dan perusahaan akan turut memberi kesan terhadap tahap kesejahteraan subjektif dalam kalangan peserta program.

Secara keseluruhannya, berdasarkan kumpulan tahap pendidikan responden seramai 304 orang atau $98.4 \%$ responden dari pelbagai latar belakang pendidikan bersetuju bahawa faktor pasaran dan persaingan merupakan aspek yang penting dalam menentukan kejayaan dan kegagalan perniagaan atau perusahaan yang mereka jalankan. Sementara itu, tiga (3) orang responden (1\%) tidak pasti dengan faktor tersebut dan dua (2) orang responden $(0.6 \%)$ tidak bersetuju dengan faktor tersebut.

\subsection{Jumlah tanggungan berbanding faktor pasaran dan persaingan}

Terdapat lima (5) kumpulan jumlah tanggungan yang dikenal pasti seperti dalam Jadual 7.

Jadual 7: Jumlah tanggungan responden (kajian lapangan, 2019).

\begin{tabular}{|l|l|c|c|c|c|}
\hline \multicolumn{2}{|c|}{ Indikator } & $\begin{array}{c}\text { Tidak } \\
\text { setuju }\end{array}$ & $\begin{array}{c}\text { tidak pasti } \\
\text { / tiada } \\
\text { perubahan }\end{array}$ & setuju & Jumlah \\
\hline \multirow{4}{*}{$\begin{array}{l}\text { Jumlah } \\
\text { tanggungan } \\
\text { (a7) }\end{array}$} & Tiada tanggungan & 0 & 0 & 6 & 6 \\
\cline { 2 - 6 } & 1-2 orang & 0 & 0 & 53 & 53 \\
\cline { 2 - 6 } & 3-4 orang & 0 & 0 & 107 & 107 \\
\cline { 2 - 6 } & 5-6 orang & 0 & 1 & 119 & 120 \\
\cline { 2 - 6 } & Lebih daripada 7 orang & 0 & 0 & 23 & 23 \\
\hline \multicolumn{2}{|l|}{ Jumlah } & 0 & 1 & 308 & 309 \\
\hline
\end{tabular}

Berdasarkan jadual di atas, didapati 100\% responden dalam kumpulan tiada tanggungan (enam orang), tanggungan 1-2 orang (53 orang) dan tanggungan seramai 3-4 orang (107 orang) bersetuju faktor pasaran dan persaingan adalah halangan dan cabaran yang utama kepada perkembangan perniagaan dan perusahaan peserta AIM. Sementara itu, kumpulan responden yang mempunyai tanggungan seramai 5-6 orang yang berjumlah 120 orang, seramai 119 orang (99.2\%) bersetuju, dan seorang (1) responden $(0.8 \%)$ tidak pasti dan tiada responden yang tidak bersetuju faktor berkenaan adalah halangan dan cabaran kepada peserta program. Bagi kumpulan responden yang mempunyai tanggungan melebihi daripada 7 orang adalah seramai 23 orang, dan keseluruhan 
responden (100\%) turut bersetuju bahawa faktor pasaran dan persaingan sebagai halangan dan cabaran kepada peserta. Secara keseluruhannya, didapati bahawa daripada 309 orang responden yang terlibat dalam kajian ini, seramai 308 orang atau 99.7\% daripada jumlah populasi kajian bersetuju bahawa faktor pasaran dan persaingan menjadi halangan dan cabaran kepada peserta program untuk mencapai kejayaan dalam perniagaan dan perusahaan mereka. Hanya seorang (1) responden $(0.3 \%)$ sahaja yang tidak pasti dengan faktor tersebut.

\subsection{Pendapatan isi rumah berbanding faktor pasaran dan persaingan}

Sebanyak enam (6) kumpulan pendapatan isi rumah dikenal pasti berdasarkan kumpulan responden seperti Jadual 8 di bawah.

Jadual 8: Kumpulan pendapatan isi rumah (kajian lapangan, 2019).

\begin{tabular}{|llcccc|}
\hline & Indikator & $\begin{array}{c}\text { Tidak } \\
\text { setuju }\end{array}$ & $\begin{array}{c}\text { tidak pasti } \\
\text { / tiada } \\
\text { perubahan }\end{array}$ & setuju & Jumlah \\
Jumlah & kurang dari RM1000.00 & 0 & 0 & 8 & 8 \\
pendapatan & RM1001.00-RM1999.00 & 1 & 2 & 59 & 62 \\
isi rumah & RM2000.00-RM2999.00 & 0 & 1 & 141 & 142 \\
sebulan & RM3000.00-RM3999.00 & 1 & 0 & 86 & 87 \\
*a10* & RM4000.00-RM4999.00 & 0 & 0 & 7 & 7 \\
& Lebih dari RM5000.00 & 0 & 0 & 3 & 3 \\
Jumlah & & 2 & 3 & 304 & 309 \\
\hline
\end{tabular}

Berdasarkan analisis data, kumpulan pendapatan isi rumah yang berpendapatan kurang daripada RM1000.00 seramai lapan (8) orang responden, dan keseluruhan responden (100\%) bersetuju bahawa faktor pasaran dan persaingan adalah halangan dan cabaran utama dalam perniagaan dan perusahaan yang diusahakan oleh peserta AIM. Bagi kumpulan peserta yang mempunyai pendapatan isi rumah antara RM1001-1999.00 pula menunjukkan seramai 62 orang peserta berada dalam kategori tersebut. Seramai 59 orang $(95.2 \%)$ daripada kumpulan berkenaan bersetuju dengan faktor pasaran dan persaingan sebagai penghalang dan cabaran kepada mereka. Seorang (1) responden (1.6\%) tidak bersetuju dengan faktor tersebut, sementara dua (2) orang responden $(3.2 \%)$ tidak pasti sama ada faktor ini memberi kesan terhadap perniagaan dan perusahaan mereka.

Kumpulan isi rumah berpendapatan RM2000-2999.00 pula seramai 142 orang dan 141 orang responden $(99.3 \%)$ bersetuju bahawa faktor pasaran dan persaingan adalah halangan dan cabaran yang utama kepada mereka. Sementara seorang (1) responden (0.7\%) tidak pasti dengan faktor ini. Kumpulan responden yang berpendapatan isi rumah antara RM3000-3999.00 seramai 87 orang. Berdasarkan jumlah tersebut, seramai 86 orang responden (98.9\%) bersetuju dengan faktor pasaran dan persaingan sebagai halangan dan cabaran kepada mereka dan hanya seorang (1) responden (1.1\%) yang tidak bersetuju dengan faktor berkenaan. Kumpulan berpendapatan RM4000-4999.00 adalah seramai tujuh (7) orang dan berpendapatan lebih daripada RM5000.00 seramai tiga (3) orang. Kedua-dua kumpulan 
ini menunjukkan keseluruhan responden bersetuju (100\%) dengan faktor pasaran dan persaingan sebagai halangan dan cabaran utama kepada mereka. Secara keseluruhannya, didapati sejumlah 309 orang responden yang meliputi 304 orang $(98.2 \%)$ bersetuju dengan faktor pasaran dan persaingan sebagai halangan dan cabaran utama kepada peserta program AIM dalam memastikan perniagaan dan perusahaan mereka berjaya. Tiga (3) orang responden (1\%) tidak pasti dengan faktor tersebut, dan dua (2) orang responden $(0.6 \%)$ yang lain tidak bersetuju dengan faktor berkenaan.

\section{Perbincangan}

Berdasarkan kepada temu bual yang dijalankan terhadap 19 orang responden juga mencatatkan bahawa keseluruhan responden bersetuju faktor sikap serta pasaran dan persaingan memberi kesan terhadap projek yang diusahakan. Responden berpandangan, sikap memainkan peranan paling utama dalam kalangan peserta program. Kegagalan responden untuk berfikiran positif, dan sering berfikiran negatif tidak membantu dalam mengembangkan perniagaan atau perusahaan mereka. Hal ini bermakna untuk berjaya seseorang itu perlu bersikap positif dan yakin dengan apa yang diusahakan. Sikap peserta program juga mempengaruhi hubungan dengan pelanggan. Kemampuan menarik pelanggan, layanan mesra, sentiasa tersenyum, bersedia menerima teguran, dan sentiasa bersedia berubah. Berdasarkan maklum balas responden menerangkan bahawa terdapat usahawan yang gagal berubah, tidak prihatin terhadap perkembangan dan kehendak semasa akan ketinggalan dan gagal pada akhirnya. Pendekatan perubahan berdasarkan kepada permintaan dapat menarik lebih ramai pelanggan kerana pasaran hari ini telah berubah dan segmen pelanggan juga berbeza daripada aspek umur, pendidikan dan latar belakang.

Antara sikap yang menyebabkan kegagalan perniagaan atau perusahaan seperti bersikap sambil lewa terhadap perniagaan. Peserta yang tidak menerima pandangan atau saranan daripada pelanggan akan mula kehilangan pelanggan. Sikap tidak mengamalkan perancangan dan strategi perniagaan seperti mengenal pasti jumlah pelanggan, kehendak, keperluan pasaran menyebabkan responden gagal dalam perniagaan atau perusahaan. Selain itu, antara masalah yang dikenal pasti adalah tidak menjalankan perniagaan secara konsisten, terlalu ghairah untuk berkembang, tiada minat yang mendalam, tiada pengetahuan asas perniagaan, cepat mengalah dan kecewa, tidak sanggup menghadapi risiko, malas dan tidak ingin berubah. Sehubungan dengan itu, sikap adalah antara faktor utama kejayaan dan kegagalan peserta. Hal ini demikian kerana kemahuan diri itu adalah perkara pokok dalam kejayaan perniagaan atau perusahaan yang mereka lakukan. Tanpa sikap yang positif dan kemampuan untuk berdikari, berubah dan bersedia untuk mengambil risiko perniagaan akan mengakibatkan projek yang diusahakan tidak berkembang dan berdepan dengan kesukaran.

Faktor kedua yang menjadi halangan dan cabaran kepada peserta program adalah berkaitan dengan pasaran. Pasaran yang terhad, tidak meluas, tidak mempunyai jumlah pelanggan yang mencukupi untuk berkembang. Selain itu, persaingan jenis perniagaan atau perusahaan yang sama dijalankan oleh peniaga dan pengusaha lain di tempat/lokasi yang sama atau berhampiran. Masalah ini timbul berikutan dalam satu kawasan yang kecil terdapat banyak peniaga dan pengusaha yang menjalankan perniagaan dan perusahaan yang sama seperti perniagaan nasi lemak, nasi ayam, kedai runcit, menjual buah-buahan, kuih-muih, pakaian, perkhidmatan van sekolah dan kedai jahitan. Jumlah pasaran yang terhad dan persaingan menyebabkan penawaran melebihi permintaan. Antara

e ISSN 2735 - 1904

https://doi.org/10.22452/JOMAS.vol31no1.2 
kesan yang diterima seperti berlaku pengurangan hasil jualan, produk yang dijual tidak habis, pusingan modal terganggu, kerosakan stok dan keuntungan semakin kecil.

Sekiranya peserta terlibat dalam aktiviti perniagaan berasaskan perkhidmatan akan menyebabkan jumlah pelanggan semakin kecil, permintaan berkurangan dan seterusnya mengurangkan jumlah pendapatan. Masalah ini bukan sahaja terjadi di kawasan taman perumahan seperti Damansara Damai dan Kepong, namun melibatkan kawasan luar bandar seperti Kuang dan Kundang. Berdasarkan temu bual bersama responden, mereka menyatakan bahawa kuasa beli penduduk tidak seperti sebelum ini. Peningkatan harga bekalan mentah menyebabkan peniaga menaikkan harga barangan dan perkhidmatan yang ditawarkan. Pertambahan jumlah peniaga dan pengusaha baru yang menjalankan perniagaan dan perkhidmatan yang sama dalam satu kawasan menyebabkan perkara ini menjadi lebih serius. Responden berharap kelembapan ekonomi ini tidak akan berterusan dan pulih seperti sediakala sedikit masa lagi. Hal ini pernah terjadi pada tahun 1997/1998 dan pada tahun 2008/2009 yang memberi kesan terhadap perniagaan dan perusahaan responden. Namun begitu, peserta program yang telah lama berniaga masih bertahan sehingga ke hari ini.

\section{Kesimpulan}

Secara keseluruhannya, kajian mendapati sepuluh (10) faktor yang menjadi halangan dan cabaran kepada responden, antaranya faktor sikap dan pasaran/persaingan paling banyak memberi kesan kepada responden berbanding faktor lain. Perbezaan antara faktor tersebut tidak begitu signifikan, iaitu hanya 1.3\% (99.7\% responden bersetuju dengan faktor sikap berbanding faktor pasaran/ persaingan sebanyak 98.4\%). Kombinasi faktor sikap amat penting kerana tanpa inisiatif kendiri, responden tidak dapat berubah kerana mentaliti dan kemahuan untuk berubah terletak kepada diri sendiri. Responden sendiri perlu sedar dan peka kerana tanpa sikap yang positif seperti fokus, tidak berputus asa, bijak menangani masalah, proaktif, kecekapan pengurusan masa, berpandangan jauh, bersikap terbuka terhadap pandangan dan kritikan, berani mengambil risiko, mempunyai wawasan, optimistik, kreatif, dan bertanggungjawab, projek yang diusahakan sukar untuk mencapai kejayaan.

Selain sikap, faktor yang berkaitan dengan pasaran dan persaingan menjadi perkara utama dalam menentukan kejayaan perniagaan dan perusahaan. Persaingan yang sengit di kawasan yang populasi penduduknya agak rendah memberi kesan terhadap projek. Perkembangan dan kemajuan projek turut memberi kesan kepada tahap kesejahteraan subjektif responden. Peningkatan projek membawa impak kepada perolehan pendapatan mereka sekali gus memberi kesan terhadap perbelanjaan harian, keperluan modal pusingan dan pengurusan keluarga. Oleh sebab itu, faktorfaktor ini berkait rapat antara satu sama lain kerana setiap faktor ini membawa kesan yang signifikan dalam tempoh masa pendek atau panjang. Kejayaan projek akan membawa kesan positif dalam kehidupan secara keseluruhan dan pada masa yang sama turut dapat meningkat tahap kesejahteraan subjektif peserta program. Begitu juga sebaliknya, sekiranya perancangan terhadap projek tidak berjalan dengan baik, berdepan dengan pelbagai masalah menyebabkan tahap kesejahteraan subjektif responden akan turut terjejas. 


\section{Rujukan}

Abd. Wahab, Zulfikri, Kurniawan, Yohan \& Abd. Wahab, Haris. (2013). Pengurusan masalah sosial yang berlaku dalam komuniti pesisir di Kelantan. Jurnal Pengajian Melayu/Journal of Malay Studies (JOMAS), [S.1.], v. 24, n. 1, p. 56-77, Dec. 2013.

Abd. Wahab, Haris (2010). Penglibatan Masyarakat Melayu dan Pencapaian Program Pembangunan Komuniti Luar Bandar. Jurnal Pengajian Melayu/Journal of Malay Studies (JOMAS), [S.1.], v. 21, n. 1, p. 47 - 74, Dec. 2010.

Arnold Matzdorff. (2015). Preliminary validation and Aftikaans translation of Personal WellBeing Index - School Children amongst a sample of children in Cape Town. Retrieved from https://etd.uwc.ac.za/bitstream/handle/11394/4998/Matzdorff_a_ma_chs_2015. pdf? sequence $=1 \&$ isAllowed $=y$.

Belinda Davey. (2004). Failure of Homeostatic Subjective Well-Being as a Model for Depression: An Empirical Study. Retrieved from http://vhost47.hosted-sites.deakin.edu.au/publications/ resources/thesis-davey-b.pdf.

Caterina Arcidiacono \& Salvatore Di Martino. (2016). A Critical Analysis of Happiness and Wellbeing: Where we stand now, where we need to go. Retrieved from https://www.researchgate. net/publication/298791567_A_Critical_Analysis_of_Happiness_and_Well-Being_Where_ we_Stand_Now_Where_we_Need_to_Go.

Chamhuri, S., \& Surtahman, K. (2000). Ekonomi Malaysia (Ed. ke-4 ed.). Petaling Jaya, Selangor: Pearson Education (M).

Changingminds.org. (2017). Subjective Well-Being. Retrieved from http://changingminds.org/ techniques/happiness/well_being.htm\#nav.

Dewi, Novita. (2017). Pengaruh Kemiskinan dan Pertumbuhan Ekonomi Terhadap Indeks Pembangunan Manusia di Provinsi Riau. Jurnal Fekon Vol.4, No 1. 870-882.

Diener, Ed. \& Diener R.B. (2001). Will money increase subjective well-being? Retrieved from https://link.springer.com/article/10.1023/A:1014411319119.

Diener, E. (2006). Guidelines for national indicator of subjective well-being and ill-being. Applied research in Quality of Life. Retrieved from https://internal.psychology.illinois.edu/ ediener/ Documents/Guidelines_for_National_Indicators.pdf.

Durayappah, Adoree. (2010). The 3P Model: A general theory subjective well-being. Retrieved from https:/www.psychologytoday.com/files/attachments/4859/the3pmodel.pdf.

Erik Angner (2009). Subjective Well-being. Retrieved from http://citeseerx.ist.psu.edu/viewdoc/ 